\title{
Lease Accounting: Back into the Past-A General Review of Different Theoretical Approaches
}

\author{
Marco Sorrentino ${ }^{1}$, Margherita Smarra ${ }^{2}$ \& Massimiliano Farina Briamonte B $^{3,4}$ \\ ${ }^{1}$ Department of Law, University of Naples "Parthenope", Italy \\ 2 Department of Economics, University of Molise, Italy \\ ${ }^{3}$ Link Campus University, Italy \\ ${ }^{4}$ Department of Economics, University of Campania "Vanvitelli", Italy \\ Correspondence: Marco Sorrentino, Department of Law, University of Naples "Parthenope", Italy. E-mail: \\ marco.sorrentino@uniparthenope.it
}

Received: December 2, 2019

Accepted: January 17, 2020

Online Published: January 27, 2020

doi:10.5539/ijbm.v15n2p136

URL: https://doi.org/10.5539/ijbm.v15n2p136

\begin{abstract}
Purpose - For better mapping the path of lease accounting research, the purpose of this paper is to offer a general review of the existing different ways accounting literature has framed leasing operations in the book-keeping model and, especially, in the accounting equation.

Design/methodology/approach - The literature reviewed consists of all the studies published in accounting academic journals available in the database 'Business Source Premier' from 1950 to July 2016 and presenting the word 'lease' or 'leasing' in the title, and the term 'accounting' in the main text.

Findings - The research has proved that while there is an overall agreement that, for accounting purposes, leasing has to be considered in the wider category of executory contracts, three main different theoretical approaches can be distinguished in literature: (i) the property right view; (ii) the firm commitment approach; and (iii) the risk and rewards approach.

Originality/value - In order to fill the gap found in the literature and the non-existence of a study clarifying the main positions concerning the theoretical interpretation and the consequent accounting recognition of leasing in its predominantly financial and trilateral configuration, this paper makes an original contribution to the lease accounting research: providing a first organic reconstruction of the main academic studies dealing with this specific issue.
\end{abstract}

Keywords: lease accounting, IFRS 16, accounting equation

\section{Introduction}

Although historically the first traces of its use were found around 2100 BC (Nevitt and Fabozzi, 1985), leasing in fact began in the United States during the seventeenth century as a financing instrument for the acquisition of wagons and horses. During the mid-1800s, in line with industrial evolution, leasing was adopted for the procurement of production factors, with large use of the rolling stock as well as construction of the network in the railway sector. In the aftermath of the Second World War, driven by an increase in the demand for consumer goods, it was also used in short-term financing (Taylor, 2011) and then spread, subsequently, as an ordering tool for the financing of companies of all sizes.

From the point of view of financial reporting, leasing, in its most characteristic and trilateral form, has from the beginning presented absolutely typical challenges (which have made it a classic example of application, or non-application, of the principle of the prevalence of economic substance over the legal form) (Meyer, 1976; Sherer, 1986; Rutherford, 1988; Maglio, 1998; Agnoli, 2005). The first attempts to define an autonomous and specific method of accounting for the operation date back to the middle of the last century when, in the United States of America, the American Institute of Certified Public Accountants (AICPA), in October of 1949, issued the ARB 38, entitled 'Disclosure of Long-Term Leases in the Financial Statements of Lessees'. Rather than standardising the various behaviours established in practice, the principle gave way to the institutionalisation of an intense debate, both doctrinal and professional (Beckman and Jarvis, 2009), which, between 1949 and 1976 , 
saw the enactment of 13 official pronouncements issued by the AICPA, the APB, the SEC and the FASB (IASB, 2007), only in the United States. This explains the intensity of the subsequent international commitment, IASC/IASB, which saw the issue of seven drafts and versions of the standard on the 'Lease' between 1980 and 2009, from the Exposure Draft n. 19 of 1980 to the last amended version of IAS 17 of April 2009. After that IASB and FASB began a complex joint project which, following the disclosure of a discussion paper, two exposure drafts and the examination of about 1,700 comment letters in total received during the different phases of the project (IASB, 2016), was completed in January 2016 with the issue of the new international standard IFRS 16, 'Lease'.

The intense elaboration of the practice is associated with an equally substantial and constant scientific production. If one performs a search on Google Scholar to find documents containing the keywords 'leasing', 'accounting', 'IASB' and 'FASB' in a single text, the academic database returns more than 10,400 results, out of which 351 were published in the first eight months of 2019. Many of the papers, at different times, have analysed and systematised the studies carried out up to that point, focusing on some of the different and multiple features to which the leasing operation has been subjected.

In this sense, Lipe (2001), concentrating on the method of accounting for operating lease transactions by the lessee and based on the assumption of the close interdependence existing between accounting information and assumed economic decisions, catalogued the numerous works according to whether they made reference to: (i) the assessment of risk by shareholders; (ii) the intrinsic value of the net worth of the lessee; and (iii) the decisions/actions put in place by the management of the lessee.

Morais (2011) conducted an organic analysis of the literature, reviewing more than 80 scientific papers and classifying them in the following five macro areas of investigation: (i) economic consequences of accounting principles; (ii) determinants in the decision to undertake a lease transaction; (iii) value relevance; (iv) evaluation of the leasing transaction; and (v) impact of leasing transactions on financial statement ratios.

More recently, Barone et al. (2014) carried out a review of recent literature analysing 44 works published between 2003 and 2013, subdividing them into two sections: the first focused on articles related to the proposal to change the accounting method of leasing transactions pursuant to the joint IASB/FASB project, now merged into the new IFRS 16; the second concerned all those studies not related to the success of the proposed amendment, but likely to provide results and/or implications of greater interest for the debate at the time and still in progress today.

In an ideal extension of the activity carried out by Lipe (2001), Spencer and Webb (2015) have examined numerous scientific products for the explicit purpose of categorising the different doctrinal opinions about: (i) the motivations that drive a company to undertake a leasing transaction, with particular regard to those of operating nature; and (ii) the methods of using information relating to operating leases by the different users of financial statement.

From this concise review, it is possible to observe the substantial absence of studies aimed at organically analysing the main positions taken by doctrine over time concerning the theoretical interpretation and the consequent accounting representation of leasing in its predominantly financial and trilateral configuration. This aspect will therefore be the main issue of this study, which will provide a systematic overview of the approaches developed in this regard, at the same time highlighting similarities and differences.

Therefore, after a preliminary description of the methodology used to identify and then analyse the different positions of the literature on the subject (section 2), this study continues with a critical representation of the completed doctrinal review (section 3), ending with the concluding remarks of the authors (section 4).

\section{Methodology}

The selection of literature for analysis was based on the methodology used by Spencer and Webb (2015) who, in their Review of Contemporary Academic Literature, made use of academic databases from which they extracted, through specific criteria research, the studies subsequently examined (Note 1).

In the present case, the Business Source Premier (Note 2) database was searched for all contributions published in academic journals presenting the word 'lease' or 'leasing' in the title, and the term 'accounting' in the main text. The search, carried out for the period between January 1950 and July 2016, returned 852 articles published in more than 70 journals. Given the high number of studies that emerged and, in any case, the relative heterogeneity of the journals identified, the examination was limited to those contributions that appeared in journals that deal with issues of accounting, namely Abacus; Accounting Perspectives; Accountancy, Accounting \& Business Research; Accounting Horizons; Accounting in Europe; Accounting Review; Australasian 
Accounting Business and Finance; CPA Journal; International Journal of Accounting; Journal of Accountancy; Journal of Accounting, Auditing \& Finance; Journal of Accounting Research; and Journal of International Financial Management and Accounting.

The subsequent analysis of the doctrine was carried out according to the following operating method:

1. Examination of all the abstracts of the contributions that emerged from the search and published in the aforementioned journals, from which those deemed most relevant to the research objective were extracted.

2. Full examination of the text of the contributions extracted following the activity carried out in the previous point. In this phase, which was inevitably the central one of the entire analysis process, the various studies reviewed were critically examined in order to derive the specific theoretical orientation regarding the phenomenon of leasing in light of the different implications with respect to the interpretation and consequent representation of the concepts of asset (Note 3) and liability (Note 4) which resulted from them.

3. Identification and examination of the studies cited in the contributions identified in the previous point that did not emerge from the search carried out through the Business Source Premier database, but that were still considered relevant to the objectives of the research.

\section{Results}

First of all, from the examination carried out, it is possible to note that, since the first half of the last century, the orientation of the academic world towards leasing has tended to be uniform, in the sense of acknowledging the need (or at least the opportunity) to recognise in the balance sheet of the lessee the asset of which the latter acquires the availability under the stipulated lease agreement and the corresponding debt to the obligations arising from it, albeit with differences in nuances with regard to the criteria for determining the respective values. This uniformity, not found in the attitudes and reactions of the protagonists of the economic world, appears to be explainable by the greater freedom enjoyed by academia with respect to those political and lobbying pressures that traditionally condition the standard setting processes (Solomons, 1978, 1983; Zeff, 2002; Booth, 2003).

The vision advocated by the academic world since 1922 can be understood in some propositions by Paton (1922, p. 57):

“(...) by means of a long-term lease the nominal owner may delegate virtually all control to the lessee. The lessor in such a case has been commonly seen as the owner, but for all practical purposes ownership, in so far as control is an essential, has passed to the lessee. Thus it is not unreasonable to view the long-term lease as in some respects the equivalent of an outright sale."

The aforementioned orientation results from an economic-substantialist view peculiar to the Anglo-Saxon context. It is not limited to the object of this study, but finds its raison d'être in the context of a broader concept of a general nature that is opposed to that typical of continental European countries, of Roman-Germanic legal tradition, in which the juridical conditioning (sometimes determined by a distorted vision of principles of protection of creditors' interest holders) ultimately limited the information capacity of financial statements, also affecting the models for recording management events. The development of capital market-based financial systems, typical of the US, Anglo-Saxon, and partly Dutch context - and of the other countries most affected by this block - has led to the development of accounting models for the recognition of management events to give precedence to the emergence of the economic impacts of the events themselves with respect to representation of the formal profiles of the underlying transactions (Nobes, 1998). As early as 1929, for example, Canning (1929, p. 14) stated that "(...) the fundamental test for determining whether a thing is or is not an asset is economic rather than legal".

In this general context, the studies reviewed have been systematised along the following three theoretical approaches, which have also been described according to their natural temporal evolution:

1. The property right view

2. The firm commitment approach

3. The risk and rewards approach.

\subsection{The Property Right View}

The first approach refers to those authors who underline that the classes of asset and liability definitions, generally accepted by literature, do not in principle exclude the possibility of recognition of executory contracts (Note 5), that means "those contracts in which both parties have not fulfilled their mutual performance or must still fulfil them in the same way" (IASB, 2011, p. 3), as explicitly stated by Wolk et al. (1992, p. 301), according 
to whom:

"There is nothing in the asset definitions presented above that would exclude recognition of executory contracts. The exclusion is by custom and seems to rest on the belief that a binding transaction has not occurred."

In this context, the so-called property right view assumes a central role, according to which an asset consists of the combination of various rights (use, conversion, sale) that a company possesses in relation to a resource at a particular time due to past transactions or events (Samuelson, 1996).

This singular interpretation of the notion of an asset is strictly functional to the possibility of recognising an alternative orientation in relation to the accounting impact of executory contracts. Indeed, this different interpretation allows the recognition of an underlying conceptual coherence in the opportunity to record both assets and liabilities as a direct consequence of the definition of this type of contract.

The application of the aforementioned reflection of a general nature to the specific leasing phenomenon defines the first theoretical orientation regarding the subject in question (Naser, 1993, p. 129).

The property right view, applied to the peculiar problem of leasing, arises explicitly from the work of Myers (1962) - 'Reporting of Leases in Financial Statements' - commissioned by AICPA in the early 1960s. The crucial and innovative element on which this research is based is the difference between the concept of property right (the right to possession of the asset) and that of right in property (the right to use the asset).

Regarding the position undertaken by the author, however, it is important to note that, just like those who opposed capitalisation of the leasing transaction, Myers (1962, pp. 38-42) claims that equally unperformed executory contracts should not be subject to accounting recognition. At the same time, however, the author does not consider leasing as an equally unperformed executory contract, and therefore justifies its inclusion in the financial statement, stating that the lessor fulfils its obligation when transferring the possession of the leased asset.

In this context, there is the relatively more recent opinion of Booth (2003, p. 318) which argues that:

"Contracts for the lease of rights are executory contracts and do involve present obligations. A lessee acquires control of the leased rights over the lease term in exchange for a present obligation to sacrifice future economic benefits equivalent to the lease rental commitments. A range of leased rights has been denied recognition as assets through the simple device of substituting ownership for control as a criterion. The adoption of ownership as a criterion has allowed the more entrepreneurial directors (and auditors) to adopt a form over substance approach to the recognition of a wide range of leased rights as assets."

In this sense, since the beginning of the 1960s, many authors have affirmed the need for the lessee company to capitalise on all leasing transactions in excess of a year (Note 6), regardless of the evaluation of their nature. According to this approach, it is believed that a lessee, at the time of stipulating a leasing contract, acquires a right to use the potential services associated with the leased asset (Vatter, 1966, p. 135) and that this acquisition determines the birth of a capital asset. Likewise, his obligations, taken on against the opportunity to avail of these future services, are well defined and present all the characteristics necessary for the identification of a liability.

At the same time, the lessor is entitled to the potential compensation of the lessee (Vatter, 1966, p. 135), which unequivocally presents all the distinctive elements of an asset. The thesis supported by Vatter is shared by many other authors of that time. Wojdak's $(1969$, p. 566) opinion is particularly interesting: he argues that the completion of any executory contract, and specifically a leasing contract, constitutes a stable transaction, or an exchange of economic benefits, having the characteristics sufficient for the recognition of accounting elements in the financial statements. In addition, the stipulation of an executory contract, according to the author, determines a transformation in the set of rights and economic obligations assumed by a company and is therefore worthy of recognition within the main accounting system. It is also important to stress that, while Wojdak identifies the question of measuring the value of these rights, judging it as a specific problem, he does not believe that this problem presents particular difficulties other than similar ones envisaged for the measurement of any conventionally recognised asset. Similar opinions, aimed at application of the property right view to the phenomenon of leasing and the identification of an accounting transaction each time a contract of this kind is concluded, are also present in Shillinglaw (1958), Hennessy (1961), Alvin (1963), Nelson (1963), Rappaport (1965) and Dieter (1979).

Furthermore, additional and more recent developments of the vision of assets in terms of property rights determine, with reference to the leasing contract, some original consequences. For example, the lessee acquires the right to use the leased asset, and not those of alienation or conversion, which are maintained by the lessor. 
Therefore, against the single resource, the leased asset, two different types of asset can be identified, one for the lessee, the other for the lessor (Rouse, 1994), differentiated according to the methods of distribution of rights determined by the rental contract and released from the material nature of the asset itself.

This theoretical approach can be considered the basis of the new IFRS 16. The following statements by Wilkins and Zimmer (1983, p. 64) show how, already in the early 1980s, the trend among the main standard-setters (in the present case, particularly in the US) to accept this doctrinal position was maturing:

“(...) Baker (Leasing and the Setting of Accounting Standards: Mapping the Labyrinth, Journal of Accounting Auditing and Finance, Spring 1980, p. 204) reported that there appeared to be a crescendo of consensus toward capitalization of all leases, and the FASB Action Alert No. 79 - 10 (8 March 1979) reported that a majority of the Board members expressed the tentative view that if SFAS No. 13 were to be reconsidered, they would support a property-right approach in which all leases would be included as rights to the use of property and as ease obligations in the lessee's balance sheet".

On this regard, Samuelson (1996) points out that in such cases it is not possible to distinguish tangible from intangible assets - or rather that the property rights are to be considered as intangible, as can be seen in the position of Shillinglaw (1958), according to whom the treatment subsequent to the initial recording of the leasing activity provides for the application of depreciation "in account", typical of intangible assets. This interpretation is confirmed by the analysis of Viganò (1969, p. 169, note n. 16) who, while not sharing this position, points out that, with some exceptions, "in the mind of American doctrine, it is an immaterial asset" (referring to the asset deriving from a financial leasing contract).

However, the profound conceptual uniformity that distinguishes this first doctrinal vein does not emerge with the same intensity also in the practical solutions suggested, over the time, by the authors who adhere to it. Although everyone agrees that the asset and liability arising from a leasing contract must be recognised on the lessee's balance sheet for the same amount, equal to the present value of the future payments associated with the contract, the same cannot be said regarding the choice of the discount rate to be used for their determination. For example, according to some authors (Myers, 1966, p. 46; Shillinglaw, 1958, pp. 583-591), the discount rate must coincide with that used by the lessor in defining the lease payments - that is to say, the implicit rate of the lease transaction or in any case an interest rate that approximates the latter as much as possible (as the use of a different rate would alter the resulting book value of the assets and liabilities) -; according to Vatter (1966, p. 137), one of the most authoritative exponents of the application of the property right view to the leasing, it should be determined with reference to the overall economic and financial positions of the lessee and the lessor, with the consequence that the lessee, having to highlight the value of the services acquired through leasing, will pay the future rents at a rate equal to its cost of capital, while the lessor will use a rate that approximates the return desired by the lease (which only occasionally coincides with the first).

\subsection{The Firm Commitment Approach}

During the early 1980s, the evolution of academic leasing thinking was significantly influenced by the opinion of Ijiri (1980), who, following a study commissioned by the FASB, made a report (Recognition of Contractual Rights and Obligations: An Exploratory Study of Conceptual Issues) which can be considered the basic element from which to derive the second theoretical position identified on this issue.

This additional doctrinal orientation, while accepting the idea of assets in terms of property right, believes that the mere completion of an executory contract does not automatically satisfy the assumption of a level of control that guarantees a substantial transfer of rights. This condition is considered satisfied when a contract becomes a firm commitment. Both contractors, therefore, are entitled to a reciprocal future performance when the agreement is valued as an irrevocable commitment. This happens, always following this orientation, if it is unlikely that the underlying performance of the contract can be avoided without a severe penalty - i.e. a penalty in respect of which a company prefers to fulfil its performance in any case (Ijiri, 1980, pp. 63-67).

Over time, the notion of firmness has been dissociated from the simple legal aspect, highlighting its possible economic, social and political nature, as long as it is capable of rendering contractual performance irrevocable (Miller \& Islam, 1988, p. 76).

This approach sees the importance of the distinction between operating lease and financial lease fade away and applies discounting to all irrevocable contracts (Miller \& Islam, 1988, p. 78) - that is to say, to all those non-cancellable leasing contracts in which there is a severe penalty and therefore able of giving rise to assets (Naser, 1993). Hendriksen (1970, pp. 484-485) in the early 1970s maintained that:

"An alternative approach to the above methods of handling long-term leases is to consider them a part of the 
broader problem of long-term noncancelable commitments. (...) But, if the contract is noncancelable by either party and if each has a valid and material claim against the other, the contract should be capitalized and the discounted value of both the rights and obligations should be disclosed. (...) The distinction between long-term and short-term obligations is not important in the decision whether or not to capitalize the rights and obligations. The important criterion is the materiality of the discounted value. (...) Capitalization should be necessary only if the penalty is sufficient to act as a deterrent to unilateral default."

In this regard, it is emblematic to point out that after more than 30 years, the same author (Hendriksen, 2001, p. 603) considers it appropriate to highlight in particular the aspect of cancel ability, reformulating part of the previous statement in the following way (the reformulated part is highlighted in bold):

“(...) the distinction between long-term and short-term obligations is not as important in the decision whether or not to capitalize the rights and obligations as the question of cancel ability. The materiality of the discounted value is also an important criterion."

Miller and Islam (1988) are of the same opinion; however, they do not disregard the distinction between operating and financial leasing, underlining how it is appropriate to capitalise both financial leases and non-cancellable operating leases.

This last doctrinal vein, defining an asset as the set of rights possessed on a specific resource on the basis of defined irrevocable agreements, is assuming a predominant role in the process of identifying an adequate economic-accounting interpretation of the leasing transaction.

Numerous works in the last thirty years have testified to this line of thought and, above all, highlighted the significant accounting consequences deriving from capitalisation of the totality of non-revocable operating lease contracts. More specifically, in these studies we analyse the positive impact, in terms of greater significance, that the capitalisation of all non-cancellable leases could have on the most significant corporate ratios, as well as the consequences of this operation (Imhoff et al., 1991; Ely, 1995; Imhoff et al., 1997; Beattie et al., 1998; Phillips et al., 2002; Bennett \& Bradbury, 2003; Kilpatrick \& Wilburn, 2006; Mulford \& Gram, 2007; Durocher, 2008; Fülbier et al., 2008; Cordazzo \& Lubian, 2015; Wong \& Joschi, 2015) (Note 7).

\subsection{The Risk and Rewards Approach}

The last doctrinal line to be considered starts from the distinction between two different types of lease. It is the one accepted by the main standard setters worldwide for the definition of the respective accounting principles on leasing prior to the new IFRS 16 (Note 8).

If the characteristics of the contract are such as to transfer to the rental company the large part of the risks and benefits associated with the leased asset, essentially generating economic effects similar to those deriving from an instalment purchase, the leasing contract is precisely equivalent to a purchase by instalment payment; thus, it becomes the object of capitalisation (Naser, 1993). In this case, the lease transaction, by virtue of its economic-substantial characteristics, is defined as financial and involves the leasing of the leased asset and the corresponding loan debt on the lessee's balance sheet.

Otherwise, the lease transaction is simply a mutual exchange (between lessor and lessee) of non-binding promises and is not therefore considered able to generate accounting assets and liabilities (Wolk et al., 1992). Rather, the lessor and the lessee record, respectively, positive and negative components of income as the reciprocal services are performed. It is common to see doctrinal positions in the literature which, in analysing the lease operation, accept these conceptual arguments, simply recalling the solutions adopted in the various standards (McCullers \& Schroeder, 1978, pp. 329-344; Glautier \& Underdown, 1991, p. 173; Belkaoui, 1992, p. 398; Williams et al., 1995, pp. 394-397; Horngreen et al., 1999, pp. 644-646; Lewis \& Pendrill, 2000, pp. 171-174; Sutton, 2000, pp. 335-336; Schroeder et al., 2001, pp. 384-404).

On the basis of this orientation, it is possible to identify an in/out empirical logic, based on which ascertaining the transfer in favour of the lessee of the large part of the risks and benefits associated with the leased asset is assumed as a key condition sufficient to define the whole passage of the entire asset in the transaction, which is identified with the leased asset. In this case, therefore, the presence of a unitary flow of resources is found which, initially controlled by the lessor, becomes the object of immediate and direct transfer to the lessee upon verification of the aforementioned condition. Therefore, if, in principle, a logic of this kind should make it possible to identify clearly the situations analysed from time to time in the specific leasing circumstance, this approach is often incorporated as one of the main limits of the theoretical orientation it represents. Significant in this regard is the opinion of Beattie et al. (2000, p. 429, note 1), who state that:

“(...) First, lease contract terms lie on a 'continuum'. At one extreme is the contract in which it is clear that the 
lessor is essentially providing finance for the purchase of an asset by the lessee. At the other, the nature of the contract is that the lessee is paying a rental for the use of the asset, usually over a short period with no commitment other than the rental payment. However, the vast majority of contracts lies in the middle of the continuum and do not fit neatly into either category. The distinction between the two lease types often does not relate to a fundamental difference in their characteristics. Rather, it relates to a desire to meet the essentially 'arbitrary' accounting classification criteria in order to keep leased assets and liabilities off the balance sheet."

Not surprisingly, intense criticisms were made right from the beginning by that part of the academic world which, by negatively judging the decisions taken on the accounting treatment of leasing by the standard setters, did not share the theory just described. In 1977, Most (1977, p. 336) emphasised the lack of application to the phenomenon of leasing of the concepts of generally accepted assets and liabilities, noting the unnecessary complexity of FAS 13, which was not based on a clear interpretation of the lease transaction. Likewise, immediately after the issue of SSAP 21, Carr (1985, pp. 119-120) maintained that the contradictions present in both the UK and the US principle were so numerous as to render their adequate interpretation more important than the correct understanding of the transactions to which one applies them.

More recent doctrinal opinions have revealed the high applicative discretion favoured by the theoretical interpretation of which we have spoken. Criticisms of the accounting principles on leasing prior to IFRS 16 (which has been compulsorily applied from 1 January 2019), and therefore implicit in the conceptual structure from which they derive, are present in many other works that deal with this issue (Dieter, 1979; Vergoossen, 1992; Wolk et al., 1992, pp. 531-535; Naser, 1993, pp. 127-133; Reither, 1998; McBarnet \& Whelan, 1999, pp. 146-148).

\section{Conclusions}

\subsection{Contributions and Implications}

Since its early use, leasing has played a leading role in the management and financial dynamics of a company. Its application has never ceased to spread for innumerable reasons, among which is the ability of user companies to procure important long-term production factors without having to immobilise their financial resources (IASB, 2016).

The spread of the phenomenon together with its quantitative relevance explain the liveliness of the debate acknowledged both in the application and regulatory context and in academic one - a debate so lively as to stimulate various reviews that, cyclically, have tried to systematise the different opinions of the doctrine on specific aspects of the subject analysed in this paper (Lipe, 2001; Morais, 2011; Barone et al., 2014; Spencer \& Webb, 2015).

However, what has probably been lacking in such a wide range of studies and attempts at systematisation has been a conceptually organic reconstruction of the various positions that emerged in the accounting literature concerning the theoretical interpretation and the subsequent representation on the balance sheet of the leasing transaction. This is a gap that we have sought to satisfy through this contribution.

The analysis carried out allowed us to conclude that leasing falls within the category of executory contracts (Vatter, 1966; Viganò, 1969; Wojdak, 1969; Most, 1977; Miller \& Islam, 1988; Kam, 1990; Wolk et al., 1992) that is, "those contracts to which the accounting practice traditionally does not attribute all the characteristics necessary to allow the recognition of an asset (and a corresponding liability) in the financial statement" (Mathews \& Perera, 1991, p. 137). In this sense, since 1929, also Canning (1929, p. 22) explicitly excluded these types of operations from the definition of assets, stating that "an asset is any future service in money or any future service convertible into money (except those services arising from contracts the two sides of which are proportionately unperformed) the beneficial interest in which legally or equitably secured to some person or set of persons". So, the accounting rules in several circumstances have imposed, or permitted, a limited representation in the financial statements of the effects of leasing contracts.

On the other hand, the theme of identifying the minimum conditions for the recognition of an asset has been evolving in recent decades (Sorter \& Horngren, 1962; Pope \& Walker, 2003; Tizzano, 2003; Pizzo, 2005, 2007), especially based on the qualifying characteristics of assets and liabilities and the minimum requirements deemed necessary for their accounting recognition. If, from both an economic and a legal point of view, it is undeniable that whoever signs a leasing contract assumes rights and obligations, the representation of these (or better, the economic and financial elements behind them) in the financial statements depends, first of all, on the aforementioned conditions and requirements.

The present review was carried out by identifying, as a discriminating element for the systematisation of the 
various theoretical orientations, the criterion used from time to time to define the concept of asset (and consequently of liability) accounting. The analysis carried out thus made it possible to identify and categorise three different and specific basic approaches, namely: (i) the property right view, according to which an asset consists of the combination of various rights (use, conversion rights of sale) that, in a particular moment, an entity owns on a resource; (ii) the firm commitment approach, which reinforces the theoretical orientation underlying the property right view, but imposes the requirement of the irrevocability of contractual agreements for the purpose of recognising the asset; and (iii) the risk and rewards approach, which assumes the transfer of a large part of the risks and benefits associated with it as a key condition for the recognition of an asset.

The following synoptic table gives a summary view of the main results of the doctrinal review carried out.

Table 1. Identified theoretical approaches

\begin{tabular}{|c|c|c|c|}
\hline & property right view & firm commitment approach & risk and rewards approach \\
\hline Reference period & Beginning of the 1960 s & Beginning of the $1980 \mathrm{~s}$ & $1990 \mathrm{~s}$ \\
\hline Main work & $\begin{array}{l}\text { Reporting of } \begin{array}{l}\text { Leases in } \\
\text { Financial }\end{array} \\
\text { Statements } \\
\text { (Myers, 1962) }\end{array}$ & $\begin{array}{l}\text { Recognition of Contractual } \\
\text { Rights and Obligations: An } \\
\text { Exploratory Study of Conceptual } \\
\text { Issues (Ijiri, 1980) }\end{array}$ & $\begin{array}{l}\text { There is no reference work. This } \\
\text { approach derives from the setting } \\
\text { that the main Anglo-Saxon standard } \\
\text { setters (FASB, IASB, FRC, AASB) } \\
\text { used to define the respective } \\
\text { accounting principles on the subject } \\
\text { before the new IFRS } 16 \text {. }\end{array}$ \\
\hline Concept of asset & $\begin{array}{l}\text { Combination of rights of use, } \\
\text { conversion and sales which, at } \\
\text { a moment, are possessed on a } \\
\text { resource. }\end{array}$ & $\begin{array}{l}\text { Combination of various irrevocable } \\
\text { rights which, at a moment, are } \\
\text { possessed on a resource. }\end{array}$ & $\begin{array}{l}\text { Resource of which you own most of } \\
\text { the risks and benefits associated with } \\
\text { it. }\end{array}$ \\
\hline $\begin{array}{l}\text { Accounting } \\
\text { representation (for } \\
\text { the lessee) }\end{array}$ & $\begin{array}{l}\text { Capitalisation } \quad \text { of } \\
\text { transactions } \\
\text { year. }\end{array}$ & $\begin{array}{l}\text { Capitalisation of all non-cancellable } \\
\text { transactions. }\end{array}$ & $\begin{array}{l}\text { Capitalisation of only those } \\
\text { operations that determine the transfer } \\
\text { of most of the risks and benefits } \\
\text { associated with the leased asset. }\end{array}$ \\
\hline \multirow{13}{*}{$\begin{array}{l}\text { Authors who share } \\
\text { the theoretical } \\
\text { approach }\end{array}$} & & \multicolumn{2}{|l|}{ Hendriksen $(1970 ; 2001)$} \\
\hline & & Miller and Islam (1988) & \\
\hline & Shillinglaw (1958) & Imhoff et al. (1991) & McCullers and Schroeder (1978) \\
\hline & Hennessy (1961) & Ely (1995) & Glautier and Underdown (1991) \\
\hline & $\begin{array}{l}\text { Alvin (1963) } \\
\text { Nelson (1963) }\end{array}$ & Imhoff et al. (1997) & Wolk et al. (1992) \\
\hline & \multirow[t]{2}{*}{ Rappaport (1965) } & Beattie et al. (1998) & Belkaoui (1992) \\
\hline & & Phillips et al. (2002) & Williams et al. (1995) \\
\hline & \multirow{2}{*}{ Wojdak (1969) } & Bennett and Bradbury (2003) & Horngreen et al. (1999) \\
\hline & & Kilpatrick and Wilburn (2006) & Lewis and Pendrill (2000) \\
\hline & $\begin{array}{l}\text { Dieter (1979) } \\
\text { Rouse (1994) }\end{array}$ & Mulford and Gram (2007) & Sutton (2000) \\
\hline & \multirow{3}{*}{ Booth (2003) } & Durocher (2008) & Schroeder et al. (2001) \\
\hline & & Fülbier et al. (2008) & \\
\hline & & Wong and Joschi (2015) & \\
\hline
\end{tabular}

Source: Authors' adjustment.

Thanks to the analysis carried out and to the subsequent systematisation, it is possible to see how the historical evolution of the interpretation of the leasing operation found in the academic literature is diametrically opposed to that performed in international accounting practice. The new accounting standard issued by the IASB on the subject is essentially based on the oldest theoretical approach identified, by virtue of which the argument that a 
lease contract should involve the recognition of an asset and a liability in the lessee's accounts is to be found not so much in the substantial equivalence of the lease with a purchase transaction with instalment payment as in the mere transfer of rights-connected to the leased resource.

We are therefore faced with a true return to the past.

According to the new provisions of the practice, there will no longer be a unitary flow of resources identified with the leased asset, which is transferred in its entirety from the lessor to the lessee, solely evaluating the occurrence of the generic condition of 'substantially all risks and rewards'. On the contrary, a gradual aspect is introduced which makes it possible to define the leasing activity more simply in terms of entitlement to use a flow of potential services, by virtue of which the problems of high discretion relative to the identification process of the asset being leased are, in part at least, limited. These are problems with which most of the criticisms addressed by the doctrine in the last theoretical orientation identified are associated.

\subsection{Limitations and Future Research}

On the basis of the overall analysis just outlined, some possible further perspectives of investigation, which stem from the limitations of the study, could aim to extend the population of the contributions reviewed. This could be implemented by modifying the combination of the words being searched for in the title and/or in the main text, by expanding the reference period, or by replicating the same selection method but making use of additional databases. Since the objective of the present work is to carry out a conceptually organic reconstruction of the different theoretical positions emerging in the accounting literature, such an activity could lead to the achievement of a systematisation characterised by a higher degree of reliability.

In addition, it could be interesting to carry out an analysis, typical of international accounting studies (Nobes \& Parker, 2010), aimed at identifying the possible underlying factors that led to the emergence of the different approaches here identified.

\section{References}

Agnoli, N. (2005). Il principio della prevalenza della sostanza sulla forma. Rivista Italiana di Ragioneria and di Economia Aziendale, (5), 595-610.

Alvin, G. (1963). The Execution of the Nonfinancial Lease - An Accounting Transaction? NAA Bulletin.

Baker, C. R. (1980). Leasing and the Setting of Accounting Standards: Mapping the Labyrinth. Journal of Accounting Auditing and Finance, 3, 197-206.

Barone, E., Birt, J., \& Moya, S. (2014). Lease Accounting: A Review of Recent Literature. Accounting in Europe, 1, 35-54. https://doi.org/10.1080/17449480.2014.903630

Beattie, V., Edwards, K., \& Goodacre, A. (1998). The impact of constructive operative lease capitalisation on key accounting ratios. Accounting and Business Research, 4, 233-254. https://doi.org/10.1016/j.sbspro.2015.11.034

Beattie, V., Goodacre, A., \& Thomson, S. (2000). Operating leases and assessment of lease-debt substitutability. Journal of Banking \& Finance, 3, 427-470. https://doi.org/10.1016/S0378-4266(99)00045-X

Beckman, J. K., \& Jervis, K. (2009). The FASB IASB lease accounting project: implications for the construction industry. Construction Accounting and Taxation, 19, 30-35.

Belkaoui, A. R. (1992). Accounting Theory. Madrid: Academic Press.

Bennett, B. K., \& Bradbury, M. E. (2003). Capitalizing Non-cancellable Operating Leases. Journal of International Financial Management and Accounting, 2, 101-114. https://doi.org/10.1111/1467-646X.00091

Booth, B. (2003). The Conceptual Framework as a Coherent System for the Development of Accounting Standards. Abacus, 3, 310 -324. https://doi.org/10.1111/j.1467-6281.2003.00135.x

Canning, J. B. (1929). The Economics of Accountancy: A Critical Analysis of Accounting Theory. New York: Ronald Press.

Carr, J. (1985). Why Accounting for lease is inconsistent. Accountancy, 1193.

Cloud, D., Smith, J. F., \& Waters, E. D. (1987). When is a liability not a liability? The National Public Accountant, 12, 42-47.

Cordazzo, M., \& Lubian, L. (2015). L'impatto della capitalizzazione del leasing operativo sulla 
performance economico-finanziaria delle imprese quotate italiane. Rivista Italiana di Ragioneria and di Economia Aziendale, 1, 21-30. https://doi.org/10.17408/RIREAMCLL000102032015

Dieter, R. (1979). Is Lessee Accounting Working? The CPA Journal, 13-19.

Durocher, S. (2008). Canadian Evidence on the Constructive Capitalisation of Operating Leases. Accounting Perspectives, 3, 227-256. https://doi.org/10.1506/ap.7.3.2

Elam, R. (1975). The effect of lease data on the predictive ability of financial ratios. The Accounting Review, 1, 25-43.

Ely, K. M. (1995). Operating Lease Accounting and the Market's Assessment of Equity Risk. Journal of Accounting Research, 2, 397-415. https://doi.org/10.2307/2491495

Fülbier, R. U., Silva, J. L., \& Pferdehirt, M. H. (2008). Impact of lease capitalisation on financial ratios of listed German companies. Schmalenbach Business Review, 122-144. https://doi.org/10.1007/BF03396762

Glautier, M. W. E., \& Underdown, B. (1991). Accounting Theory and Practice. London: Pitman Publishing.

Henderson, S., \& Peirson, G. (1984). A note on Accounting and Executory Contracts. Abacus, 1, 96-98. https://doi.org/10.1111/j.1467-6281.1984.tb00193.x

Hendriksen, E. S. (1970). Accounting Theory. Richard D. Irwin, Inc. Aurora.

Hendriksen, E. S., \& Van Breda, M. F. (2001). Accounting Theory, fifth edition, McGraw-Hill International Editio. Aurora.

Hennessy, J. L. (1961). Recording of Lease Obligations and Related Property Rights. The Journal of Accountancy, 40-46.

Horngreen, C. T., Harrison, W. T., \& Smith, B. L. (1999). Accounting, Prentice-Hall International Madrid.

IASB. (2007). Board meeting papers-History of lease accounting (Agenda paper 12C), 22 March, IFRS Foundation.

IASB. (2011). IAS 37-Provisions, Contingent Liabilities and Contingent Assets, IFRS Foundation.

IASB. (2016). IFRS 16: Leases-Project Summary and Feedback Statement, IFRS Foundation, January, Retrieved from https://www.ifrs.org/-/media/project/leases/ifrs/published-documents/ifrs16-project-summary.pdf

Ijiri, Y. (1980). Recognition of Contractual Rights and Obligations: An Exploratory Study of Conceptual Issues, Research Report FASB.

Imhoff, E. A., Lipe, C. R. Jr., \& Wright, D. W. (1991). Operating Leases: Impact of Constructive Capitalisation. Accounting Horizons, 1, 51-63. https://doi.org/10.1016/j.sbspro.2015.11.034

Imhoff, E. A., Lipe, C. R. Jr., \& Wright, D. W. (1997). Operating Leases: Income Effects of Constructive Capitalisation. Accounting Horizons, 2, 12-32.

Kam, V. (1990). Accounting Theory. New York: John Wiley \& Sons.

Kerr Jean, St. G. (1984). The Definition and Recognition of Liabilities. AARF. Melbourne.

Kilpatrick, B. G., \& Wilburn, N. L. (2006). Off balance sheet financing and operating lease: Impact on lessee financial ratios. RMA Journal, 4, 80-87.

Kohler, E. (1957). Dictionary for Accountants. New Jersey: Englewood Cliffs, Prentice-Hall.

Lewis, R., \& Pendrill, D. (2000). Advanced Financial Accounting. Harlow: Prentice Hall.

Lipe, C. R. (2001). Lease Accounting Research and the G4+1 Proposal. Accounting Horizons, 3, 299-310. https://doi.org/10.2308/acch.2001.15.3.299

Ma, R., \& Miller, M. C. (1978). Conceptualising the liability. Accounting and Business Research, 8, 258-265. https://doi.org/10.1080/00014788.1978.9728728

Maglio, R. (1998). Il principio contabile della prevalenza della sostanza sulla forma. Cedam, Padova.

Mathews, M. R., \& Perera, M. H. B. (1991). Accounting Theory and Development. London: Chapman \& Hall.

Mcbarnet, D., \& Whelan, C. (1999). Creative Accounting and Cross-Eyed Javelin Thrower. John Wiley \& 
Sons, LTD

Mccullers, L. D., \& Schroeder, R. G. (1978). Accounting Theory. John Wiley \& Sons.

Meyer, P. E. (1976). A framework for understanding substance over form in accounting. The Accounting Review, 1, 80-89.

Miller, M. C., \& Islam, M. A. (1988). The Definition and Recognition of Assets. AARF, Melbourne.

Morais, A. I. (2011). Accounting for Leases: A Literature Review. Bamberg: EUFIN.

Most, K. S. (1977). Accounting Theory. Grid Inc., Columbus, Ohio.

Mulford, C. W., \& Gram, M. (2007). The Effects of Lease Capitalisation on Various Financial Measures: An Analysis of the Retail Industry. Journal of Applied Research in Accounting and Finance, 2, 3-23.

Myers, J. H. (1962). Reporting of Leases in Financial Statements. Accounting Research Study, 4.

Naser, K. (1993). Creative Accounting Theory: Its Nature and Use. New York: Prentice-Hall International.

Nelson, T. A. (1963). The impact of leases on financial analysis, East Lansing, Bureau of Business and Economic Research. Graduate School of Business Administration, Michigan State University.

Nevitt, P. K., \& Fabozzi, F. J. (1985). Equipment Leasing (2nd ed.). New York: Homewood.

Nobes, C. (1988). Towards a General Model of the Reasons for international Differences in Financial Reporting. Abacus, 2, 162-187. https://doi.org/10.1111/1467-6281.00028

Nobes, C., \& Parker, R. (2010). Comparative International Accounting. New York: Prentice Hall.

Paton, W. A. (1922). Accounting Theory. New York: Ronald Press.

Phillips, L. C., Munter, P., \& Robinson, T. R. (2002). Understanding leases: Accounting issues. Commercial Lending Review, 24-33.

Pizzo, M. (2005). L'iscrizione dei ricavi tra realizzazione and recognition. Cedam, Padova.

Pizzo, M. (2007). Leasing: recognition and rappresentazione in bilancio. Giappichelli, 2007, Torino.

Pope, P. F., \& Walker, M. (2003). Ex-Ante and Ex-Post Conservatism, Asset Recognition and Asymmetric Earnings Timeliness. Working Paper Lancaster University/University of Manchester.

Rappaport, A. (1965). Lease Capitalisation and the Transaction Concept. The Accounting Review, 325-332.

Reither, C. L. (1998). What are the best and worst accounting standards? Accounting Horizons, 283-292.

Riccomagno, F. (2015). IFRS 16: il nuovo principio sul trattamento dei lease per i locatari e i locatori. In A. A. V. V. (Ed.), I principi contabili internazionali a 10 anni dall'introduzione obbligatoria in Italia. Le sfide del futuro e le problematiche applicative in Italia (pp. 65-70).

Rouse, P. (1994). The Recognition of Executory Contracts. Accounting and Business Research, 97, 15-21. https://doi.org/10.1080/00014788.1994.9729925

Rutherford, B. (1998). The doctrine of substance over form. Certified Accountant Publications Limited.

Samuelson, R. A. (1996). The concept of Assets in Accounting Theory. Accounting Horizons, 3, 147-157.

Schroeder, R. G., Clark, M. W., \& Cathey, J. M. (2001). Accounting Theory and Analysis. New York: John Wiley \& Sons.

Sherer, B. (1986). Substance over Form: Fine but not as a Concept. The Accountant.

Shillinglaw, G. (1958). Leasing and Financial Statements. The Accounting Review, 4, 581-592.

Solomons, D. (1978). The politicization of Accounting. The Journal of Accountancy, 65-72.

Solomons, D. (1983). The Political Implication of Accounting and Accounting Standard Setting. Accounting and Business Research, 107-108. https://doi.org/10.1080/00014788.1983.9729739.

Sorter, G. H., \& Horngren, C. T. (1962). Asset recognition and economic attributes: The relevant costing approach. The Accounting Review, 391-399.

Spencer, A. W., \& Webb, T. Z. (2015). Leases: A Review of Contemporary Academic Literature Relating to Lessees. Accounting Horizons, 4, 997-1023. https://doi.org/10.2308/acch-51239 
Sutton, T. (2000). Corporate Financial Accounting and Reporting, Prentice Hall. Harlow/Essex

Taylor, J. (2011). The history of leasing. Finance and Business Institute.

Tizzano, R. (2003). I fattori produttivi dei terzi nei bilanci delle imprese. Nuove prospettive sul leasing, Giuffré, Milano.

Vatter, W. J. (1966). Accounting for Leases. Journal of Accounting Research, 133-148.

Vergoossen, R. G. A. (1992). The Classification of Leases by Lessees in the United States and Netherlands: A Comparative Study. The International Journal of Accounting, 3, 241-254.

Viganò, E. (1969). L'iscrizione del leasing nei conti and nei bilanci d'impresa, Giannini. Napoli.

Weirich, T. R., Churyk, N. T., \& Pearson, T. C. (2015). Accounting \& Auditing Research and Databases: Practitioner's Desk Reference. Wiley Online Library.

Wilkins, T., \& Zimmer, I. (1983). The Effects of Alternative Methods of Accounting for Leases-An Experimental Study. Abacus, 1, 64-75. https://doi.org/10.1111/j.1467-6281.1983.tb00240.x

Williams, J. R., Stanga, K. G., \& Holder, W. W. (1995). Intermediate Accounting (5th ed.). New York: The Dryden Press.

Wojdak, J. F. (1969). A Theoretical Foundation for Lease and Other Executory Contracts. The Accounting Review, 3, 562-572.

Wolk, H. I., Dodd, J. L., \& Tearney, M. G. (2004). Accounting Theory-Conceptual Issues in a Political and Economic Environment. Thompson South-Western.

Wolk, H. I., Francis, J. R., \& Tearney, M. G. (1992). Accounting Theory, A Conceptual and Institutional Approach (3rd ed.). South-Western Publishing CO., Cincinnati.

Wong, K., \& Joschi, M. (2015). The Impact of Lease Capitalisation on Financial Statements and Key Ratios: Evidence from Australia. Australasian Accounting Business and Finance, 3, 27-44. https://doi.org/10.14453/aabfj.v9i3.3

Zeff, S. A. (2002). «Political» Lobbying on Proposed Standards: A Challenge to the IASB. Accounting Horizons, 1, 43 -54. https://doi.org/10.2308/acch.2002.16.1.43

\section{Notes}

Note 1. This approach is now a consolidated practice for all those contributions whose specific objective is to review the prevalent literature on a specific topic. To confirm this, we refer you to the most recent studies published in the Review of Accounting Studies, a top international journal which, as can be deduced from the title, contains mainly such contributions.

Note 2. Produced by EBSCO International, Business Source Premier is considered one of the most used and complete academic research databases, if not the most widely used, in the economic sector, particularly with regard to the theme of accounting (Weirich et al., 2015).

Note 3. A complete critical review of the doctrinal evolution undergone by the concept of assets over the last century is carried out by Miller and Islam (1988, pp. 7-38).

Note 4. The theoretical opinions regarding the concept of liability are inevitably lower than those provided for the notion of assets. In the past, in fact, liability was considered exclusively as "(...) the consequences of an asset or a service received" (Kohler, 1957, p. 291) or "(...) the result of recognising and valuing an asset "(Mathews and Perera, 1991, p. 220). Only at a later time did this concept acquire its own autonomy and definitions follow in the doctrine that delineate liability as a (negative) element of the company's assets, independent of the activities. In this sense, we highlight Ma and Miller (1978, pp. 258-265) and Cloud et al. (1987). Moreover, it is interesting to underline how Mathews and Perera (1991) argue that it was precisely the phenomenon of leasing that laid the foundations for the formulation of an autonomous theory of liabilities, necessary for the evaluation of a financial lease transaction. However, a complete critical review of the doctrinal evolution undergone by the concept of liability over the past century is carried out by Kerr (1984, pp. 3-16).

Note 5. An examination of the different definitions of executory contract proposed over time by the doctrine is provided by Henderson and Peirson (1984). 
Note 6. The time limit identified as a year is, of course, conventional; however, it is used by most of the authors who adhere to this theoretical orientation, since it is considered congruous in distinguishing the leasing operations considered material, and therefore worthy of accounting representation, from those that are non-material.

Note 7. An eclectic vision is that of Elam (1975), who believes that the constructive capitalisation of lease agreements is rarely able to improve the signalling capabilities of the various financial statement ratios in anticipating possible financial disruptions.

Note 8. More specifically, reference is made to IAS 17, issued by the international standard setter (the IASC, now IASB); to SFAS 13, issued by the US standard setter (FASB); to SAAP 21, issued by the UK standard setter (the ASB); and to AASB 1008, issued by the Australian standard setter (AASB).

\section{Copyrights}

Copyright for this article is retained by the author(s), with first publication rights granted to the journal.

This is an open-access article distributed under the terms and conditions of the Creative Commons Attribution license (http://creativecommons.org/licenses/by/4.0/). 